\title{
The Role of the Icon in Byzantine Piety
}

\author{
By LENNART RYDÉN
}

In February 754, the bishops of the Byzantine Empire met in the imperial palace at Hiereia, a peninsula on the Asiatic side of the Sea of Marmora, not far from Chalcedon. The council had been convened by the Emperor Constantine V (741-75), who wanted the bishops to examine the scriptures and express their opinion on the "deceitful painting of likenesses, which draws away the human mind from the service which is sublime and befits the Divinity to the grovelling and material service of creatures" ${ }^{\prime}$. As the phrasing shows, the assembled bishops were not expected to discuss whether the making of icons ${ }^{2}$ was justified or not. The emperor had already examined this question and found that there was no such justification. The purpose of the council was rather to remove unorthodox elements from the emperor's argument, to give it a theological finish and to put it into a historical context. The proceedings lasted six months. In August a horos (definition) was approved, which may be summarized as follows ${ }^{3}$.

In order to separate man from God, Lucifer made man worship the creature rather than the Creator (cf. Rom. i,25). God, who wanted to save man, sent him the Law and the prophets. When man failed to return to his former state, God at last sent His own Son and Logos. Christ saved man from idolatry and taught him to worship in spirit and truth (cf. John iv,24). The Christian apostles and teachers passed on the true faith to later generations. The six ecumenical councils kept it pure. But, under the guise of Christianity, Satan again made man worship the creature rather than the Creator. He made man think that an image carrying the name of Christ was God. Thus, Satan secretly brought idolatry back.

For this reason, God has raised up our emperors, i.e. Constantine $\mathrm{V}$ and his son Leo, the future Leo IV (775-80), His servants and the equals of the apostles, to remove the icons and destroy the demonic fortifications raised by the devil to prevent man from knowing God.

There follows a brief history of the doctrinal controversies settled by the

1 Gero $1977,71$.

2 The word "icon" here stands not only for portable portraits of the saints and the other holy persons but also for such pictures made in mosaic or fresco on the walls. In Byzantine Greek, eikôn simply means image, without further limitation.

3 The acts of the Council of Hiereia have not been preserved, but the horos can be recon- structed from the proceedings of the Seventh Ecumenical Council of Nicaea (787), where it is quoted and refuted. The Greek text of the horos is conveniently available in Textus $61 \mathrm{ff}$. An English translation, with discussions, is contained in Gero 1977, $53 \mathrm{ff}$. For a summary and partial translation, cf. Anastos $178 \mathrm{ff}$. 
six ecumenical councils, from Nicaea (325) to Constantinople (680). It appears from this survey that he who makes a picture of a man and calls the man in the picture "Christ" is guilty of heresy. For either he thinks that he can circumscribe Christ's divine nature together with His human and so confuses Christ's two natures, which is monophysitism, or he says that he only wants to make a picture of Christ's flesh. But, in so doing, he gives the flesh of Christ a separate existence and adds a fourth person to the Trinity, and this is Nestorianism. The pictures of Christ that the painters produce are false pictures.

What, then, constitutes a true image of Christ? This question was answered by Christ Himself on the eve of His passion, when He took bread, blessed it and said, "This is my body," and distributed wine and said, "This is my blood." The bread and wine that pass from the realm of the common to that of the holy through the blessing of the priest constitute the only true image of the body of Christ. This image does not have the form of man and therefore does not provoke idolatrous practices.

It is further pointed out that there is no prayer that could transform the icons from mere matter into something holy.

The pictures of the Virgin, the saints and the prophets do not offer the doctrinal dilemma which makes the picture of Christ unacceptable. Yet they must be rejected. The craft of idol-making, which makes what is not present seem to be present, was invented by the pagans, as they had no hope of resurrection. It would be blasphemous to apply this illusionism to the saints. "How do they dare to depict, by means of vulgar pagan art, the Mother of God, [...] who is higher than the heavens and is more holy than the Cherubim? Or, are they not ashamed to depict with pagan art those who will reign together with Christ [...]?"4 In short, the saints, living eternally with God, do not need the art of the pagans, who try in vain to reproduce life by means of dead matter.

To support their conclusions, the bishops quote from the Old and the New Testament and from the Fathers passages that warn against idolatry and underline the spiritual character of the Christian religion.

Finally, they pronounce a number of anathemas. In the context of this symposium, the most interesting is perhaps the sixteenth anathema. Here, those are declared anathema who depict the useless forms of the saints in lifeless and dumb icons, instead of reading the saints' Lives and painting living pictures of their virtues in their own souls, thereby raising themselves to a zeal equal to theirs ${ }^{5}$.

Evidently, Constantine and his bishops were not interested in questioning the orthodox dogma, nor in changing the ideals of the Christian way of life. Their program was "Spiritual icons yes, material icons no!" The emperor probably thought that, by convening the Council of Hiereia, he had settled

${ }^{4}$ Gero $1977,79$.

${ }^{5}$ Cf. Ib. 91; Anastos 186. 
the question of icon worship once and for all. He had a strong case, and his point of view had been accepted by no less than 338 bishops. This was a very large number, especially in view of the fact that by this time Byzantium had lost substantial parts of its territory through Arab expansion and the invasion of Slavs and Bulgars on the Balkan peninsula. Yet the attempt to abolish icon worship in Byzantium failed. Why? Let us take a look at the background.

The horos is certainly right in submitting that, originally, there was no specific Christian art. There is no indication that such an art existed prior to the third century ${ }^{6}$. Nor does it seem unfair to say that pictorial art was invented by the pagans. When, in the third century, a specific Christian art began to develop, this meant that the Christians adapted themselves to a pagan society in which art in many forms played an important part ${ }^{7}$. The process of adaptation accelerated in the fourth century, when the Christian Church and the Roman State came to terms with each other. Instead of meeting in churches disguised as private houses, the Christians could now gather freely in large, splendid basilicas. These impressive buildings were soon decorated with scenes from the Bible, and the martyria were correspondingly decorated with scenes from the lives of the martyrs ${ }^{8}$. From our point of view, the most important change was that the Christians also began to make portraits of the saints and the biblical figures. This innovation took place in the latter half of the fourth century ${ }^{9}$. Thus, if one regards heathen culture as Satan and associates religious images with idolatry, one might agree with the Council of Hiereia that Satan seemed to have reintroduced idolatry under the guise of Christianity.

Constantine $\mathrm{V}$ and the bishops at Hiereia were anxious to show that they were not the first to object to the introduction of Christian religious images. In the patristic florilegium incorporated in the horos, they quoted Eusebius (d. c. 340) as already pointing out the christological dilemma which constitutes the core of the horos. The Empress Constantia, wife of Licinius and step-sister of Constantine the Great, had asked Eusebius for a portrait of Christ. Eusebius declined, explaining to her the theological implications of her request. What sort of image did she have in mind? he asked. Was it a portrait of the true, unchanging Christ or a portrait of the servant whose shape He put on for our sake? (Cf. Phil. ii, 5 ff.) No, Eusebius said, it could not be a portrait of the former, for no one has known the Father except the Son, nor will anyone know the Son properly except the Father who begot Him (cf. Matt. xi,27). Nor could it be a portrait of the latter, since the flesh of the servant was blended with the glory of the Godhead and His mortality was swallowed up by Life (cf. II Cor., 4). How could lifeless colors and outlines depict the splendors that made the disciples on Mount Tabor

6 Cf. Kitzinger 1977, 19.

7 Cf. Ib.
8 Cf. Mango 22.

9 Cf, Ib. 23. 
fall upon their faces and confess that the sight was more than they could bear ${ }^{10}$ ? They also refer to Epiphanius of Salamis (d. 403) who, according to the horos, said that the Christians should remember God in their hearts and not by setting up images in the churches or in the resting-places of the saints; nor should they set up images in ordinary houses, for a Christian should not be distracted by his eyes and the wanderings of his thoughts ${ }^{11}$. They further quote a dictum ascribed to Amphilochius of Iconium (d. c. 395), namely, that "we do not engage in depicting on tablets the bodily appearance of the saints, by means of colors, because we do not need these; rather we imitate their conduct by [our] virtues" ${ }^{12}$. And Theodotus of Ancyra (d. c. 445) is quoted as saying that "we have received [the tradition that] the appearances of the saints should not be fashioned by means of material colors; rather we have been taught to perceive their virtues, as it were living images shown forth in writings about them, so that, by means of this, our zeal should be excited to emulate them"13. This statement reappears almost word for word in the sixteenth anathema. On the other hand, the bishops at Hiereia did not mention Bishop Julian of Adramyttion, who plays an important part in modern discussions because, in the fourth decade of the sixth century, he expressed concern about the presence of images and sculptures in the churches in a way that foreshadows the beginnings of the iconoclastic controversy two centuries later ${ }^{14}$.

But, in general, the attitude to the development of an anthropomorphic Christian art does not seem to have been so hostile. To the troubled Julian of Adramyttion, Hypatius of Ephesus explained that the images could be tolerated as a useful means of helping the spiritually less advanced; he added that, personally, he did not delight in looking at the $\mathrm{m}^{15}$. It is further worth noting that neither Basil the Great (d. 379) nor John Chrysostom (d. 407) denounced pictorial art, although they spoke about spiritual and living images, as the quotations in the horos show ${ }^{16}$. Moreover, the authenticity of some of the most iconoclastic quotations, especially in the case of Eusebius, seems to be open to some doubt ${ }^{17}$, and it is also possible that the importance of certain other passages, cited by modern scholars to demonstrate the hostility of the early Church to religious art, has been somewhat exaggerated ${ }^{18}$. At any rate, none of the first five ecumenical councils, from Nicaea (325) to Constantinople (553), made any pronouncement concerning images. The reason for this reticence was apparently that the rise of Chris-

10 Cf. Gero 1977, $85 \mathrm{f}$; Anastos $183 \mathrm{f}$.

${ }^{11}$ Cf. Gero 1977, 81; Anastos 182. Unfortunately, Epiphanius does not explain what kind of images he has in mind; cf. n. 13.

${ }_{12}$ Gero 1977, 83.

13 Ib. 84. Theodotus' compatriote Nilus (d. c. 430) may have taken a similar attitude, cf. Thümmel $17 \mathrm{f}$. Yet, to judge from the text reconstructed by Thümmel, 21, Nilus' main point was that a church built in honor of Christ and the martyrs should not be decorated with secular art.

${ }^{14} \mathrm{Cf}$. Lange $44 \mathrm{ff}$; Baynes $226 \mathrm{ff}$.

${ }^{15} \mathrm{Cf}$. Lange 51 ; Baynes 228.

${ }^{16}$ Cf. Gero 1977, 82 f.

${ }_{17}$ Cf. Murray $326 \mathrm{ff}$.

${ }^{18}$ Cf. Ib. 319 ff. 
tian art did not constitute a problem in itself. As long as the images did not play a significant role in the religious life of the people, they were rather harmless. But, in the middle of the sixth century, this situation began to change. At that time, the number of pictures of holy persons started to increase, and the images began to appear in contexts where they had not been known before ${ }^{19}$. The growing importance of the image of the Virgin Mary, recently discussed by Averil Cameron, may exemplify this. The Emperor Leo I (457-74) had already put up a picture in which he and his family appeared together with the Virgin in the Virgin's church at Blachernae. Justinian I (527-65) and Theodora had been depicted in a similar way on the curtains of Hagia Sophia. But, in the reign of Justin II (565-78), the image of the Virgin appeared on bronze weights, and in the reign of Maurice (582602 ), the pagan Victoria was replaced by the Virgin and Child on seals. In 610, when the future emperor Heraclius sailed from Carthage to Constantinople, the image of the Virgin adorned the masts of his ships. In 626, when the Avars laid siege to Constantinople, the gates of the Theodosian wall were provided with representations of the Virgin for apotropaic purposes ${ }^{20}$. In the same period, we are told of so-called acheiropoieta, images "not made by hand," i.e. miraculous imprints of the face of Jesus, pictures fallen from heaven and other images of supernatural origin. During the wars against Persia, such acheiropoieta were used as banners in the same way as Constantine the Great had used the labarum. This development reached its peak in the first reign of Justin II (685-95), when, for the first time, Christ was represented on the Byzantine coins.

The increasing use of the icon as an official Christian symbol reflected a change in the religious life of individuals. Icons became common in private homes and were honored in a way in which hitherto only the image of the emperor had been honored, i.e. people bowed to them and lit candles and incense in front of them. People mistrusted doctors and feared their knives, not without reason. When they fell ill, they often preferred to consult the martyrs Cosmas and Damian or the martyr Artemius or other saints who were supposed to bring cures, i.e. they went to sleep in their churches, hoping that they would appear to them in a dream and cure them. But it also happened that the sick were cured by their private icons. For instance, we are told of a woman who fell ill but was cured when she scraped away a little paint from her icons of Cosmas and Damian, mixed it with water and drank $\mathrm{it}^{21}$.

The new attitude to the icon changed the way in which the holy persons

\footnotetext{
${ }^{19}$ For a detailed analysis of this phenomenon, cf. Kitzinger 1954, $95 \mathrm{ff}$.

${ }^{20}$ These examples I owe to Cameron 97. For the rest of this paragraph, and for the following, I am mainly relying on Kitzinger $1954,95 \mathrm{ff}$.
}

${ }^{21}$ Cf. Mansi XIII, 68 A-D. At the Council of Nicaea (787), this and similar stories were quoted in order to show that the icons were as holy as the relics and the cross. 
were represented. As Kitzinger has demonstrated, Christian art became more abstract. Christ, the Virgin and the saints lost something of their solidity; they became elongated, thin, transparent, more spiritual and less corporeal ${ }^{22}$. In church, the central figure was represented in stark isolation, not unlike a statue of a god or a goddess in a Greek temple ${ }^{23}$.

Thus, in the second half of the sixth century, the role of the icon began to change. Before the middle of the sixth century, the icons had been regarded primarily as artistic reminders of the fact that the saints had lived and worked and suffered here on earth. Now they rather expressed the beliefs that the saints were still living and accessible to man. The icons became channels, as it were, through which men could reach and associate with the holy ${ }^{24}$. Thereby the icons, or at least some of them, obviously ran the risk of being mixed up with the holy itself.

This was a sore point. The Jews, who seem to have returned to a strict observance of the Second Commandment at about the same time as the use of icons expanded within the Byzantine Empire ${ }^{25}$, seized the opportunity of accusing the Christians of idolatry and violation of the Law of Moses. The well-known hagiographer Leontius of Neapolis in Cyprus, who lived in the first half and perhaps also the third quarter of the seventh century, replied that the Old Testament was not quite so hostile to religious images as the Jews maintained ${ }^{26}$. In support of this view, he quoted Exodus Xx.18 and Ezekiel xli.18. But his main argument is that the Christians do not worship the material of which the icons are made but the holy persons which they represent. "When I am holding Christ's lifeless image," he says, "through it I think I am holding Christ and revering Him," and, "when we Christians hold an icon of Christ, or an icon of an apostle or a martyr, in our hands and kiss it with our lips, we think in our soul that we are holding Christ or His martyr"'27. Thus, according to Leontius, when the Christian worships an icon, the icon itself melts away, as it were, and a purely spiritual meeting takes place between the worshiper and the holy person represented in the icon.

In another passage, Leontius says, "Man, created in God's image, is an irnage of God, especially the man who has received the indwelling of the Holy Spirit. Therefore I rightly honor and venerate the icon of God's servants and praise the dwelling of the Holy Spirit" ${ }^{28}$. Here, Leontius is speak-

${ }^{22}$ Cf. Kitzinger 1977, $103 \mathrm{ff}$.

23 Cf. Ib. 105.

${ }^{24}$ Cf. Brown 19; Kitzinger 1954, 137.

${ }_{25}$ The chronology of the change in the Jewish attitude to figurative art is discussed by Kitzinger, 1954, 130, n. 204.

${ }_{26}$ Leontius' defense of the religious images was part of a major apology against the Jews, now lost. The section on the images was read at the Council of Nicaea (787), and has been preserved in the acts of this council. It can be studied most conveniently in PG 93, $1597 \mathrm{ff}$;; for an analysis of Leontius' arguments, cf. Baynes $230 \mathrm{ff}$;; Lange $61 \mathrm{ff}$. Lange also discusses the relation between the version read at Nicaea and the quotations appearing in the writings of John of Damascus.

27 PG 93, $1600 \mathrm{C}$.

${ }^{28}$ Ib. 1604 CD. Cf. Gen. i,27 and I Cor. iii, 16. 
ing of two kinds of images, on the one hand, of the saints as living images of God and, on the other, of the material images of the saints, which are justified by the fact that the Holy Spirit has dwelt in the bodies of these men ${ }^{29}$.

It is interesting to note that, in spite of his vigorous defense of icon worship, Leontius does not mention any icon in his famous biographies of John the Almsgiver and Symeon the Fool for the Sake of Christ, although he uses the word in a metaphorical sense; in the Life of John, he even quotes the Gospel according to St. John xx,29: "Blessed are those who have not seen and yet believe"30. In the Life of Symeon, he applies the concept of the saints and the saints' Lives as living images of virtue ${ }^{31}$ to his own role as a hagiographer, saying that he who wants to teach virtue to others ought to set up his own life as an icon of virtuous acts but, finding himself unable to do this, he confines himself to describing the virtuous achievements of other, more perfect men ${ }^{32}$. It would seem then that Leontius regarded a man imitating Christ as the real Christian image, an image of the first class, so to speak, and the painted icon of a saint as a second-class image equivalent to a saint's Life but with a different function.

In addition to these and other arguments that are supposed to demonstrate that the icons are means, not goals, Leontius also says that God has shown his approval by letting the icons work miracles ${ }^{33}$. He does not, however, use the Incarnation as an argument for icon worship, nor would this argument have made any impression on the Jews to whom his apology was addressed.

Instead, the argument from the Incarnation was referred to at the council in Trullo (692). The famous canon 82 of this council ${ }^{34}$ forbade artists to use the lamb as a means of representing Christ. Christ should be represented according to His human character, the canon stated. The lamb had foreboded Christ but, after the Incarnation had taken place, it would be wrong to stick to this ancient symbol, as if the Incarnation had never occurred. Unlike Leontius, canon 82 did not defend the icons against people who called them idols. Its aim was to remove an anachronistic religious symbol and to enjoin the artists to bring out the full meaning of the Incarnation. In

29 According to Kitzinger, 1954, $140 \mathrm{f} .$, Leeontius' use of Gen. i,27 reflects "an essentially Neoplatonic belief in the divine manifesting itself in a descending sequence of reflections. By implication at least, the work of the artist becomes an extension of the divine act of creation, a concept far removed from Early Christian indictments of the artist as a deceiver." One might add that this concept of the role of the artist is also far removed from Plato's theory of art.

30 Léontios 387, $38 \mathrm{f}$.

31 This idea, which appears as early as the writings of the Cappadocian Fathers, had become a hagiographic commonplace, cf. Lange $34 \mathrm{ff} ., 90$, n. 37.

${ }^{32}$ Cf. Rydén 1963, 121. By contrast, painted icons play a conspicuous role in the Life of Andreas the Fool for the Sake of Christ, cf. PG 111, 628 ff. The author of this Vita dates Andreas and himself in the fifth or sixth centuries, although indirect evidence shows that he lived in the tenth century and that Andreas is a fictitious saint (cf. Rydén 1978).

${ }^{33}$ Cf. PG 93, 1601 CD.

${ }^{34}$ Cf. Mansi XI, 977 Eff.; Engl. transl. in Alexander 45 . 
fact, the canon appears to have been rather superfluous, since Christ had already been represented according to His human character for centuries. But it is interesting to note that this canon was written at the same time as the bust of Christ appeared on the Byzantine coins and in a period in which there was a reaction against the abstract style that had dominated Christian art since the middle of the sixth century ${ }^{35}$. In contemporary art, Christ appears as a man with the harmonious proportions of the classical ideal; at the same time he radiates something inscrutable and divine. It was toward the end of the seventh century that the prototype of the Pantokrator image was created, the best examples of which give an overwhelming impression of the meeting of the divine with the human in the body of Christ ${ }^{36}$.

In the third decade of the eighth century, this development was interrupted by iconoclastic reaction. It all started, it is said, with Bishop Constantine of Nacoleia taking measures against icon worship in his see in Phrygia because of the ban on graven images and likenesses in Exodus xx.4-5. Other bishops in Asia Minor followed suit. Patriarch Germanos I tried in vain to bring them to reason. When Emperor Leo III himself ordered the image of Christ to be removed from above the entrance of the Great Palace in Constantinople, the iconoclastic controversy broke out. Germanos, who resigned in 730 , describes the preliminaries of the conflict in the following way: "There appeared a certain bishop of Nacoleia, a small town in the eparchy of Phrygia, a man not renowned for his learning and reason, although in his folly he dreamt of demonstrating his insight. Reading the divinely inspired Scriptures, he stared open-mouthed at the bare letter and tried to introduce new false doctrines which are contrary to what has been piously proclaimed, and arm himself to rise against the traditions of the Fathers" ${ }^{37}$. In Germanos' account, Constantine of Nacoleia appears as a narrow-minded fundamentalist unable to read the prohibition in Exodus xx.4-5 in the light of the historical context and ignorant of the patristic tradition. Emperor Leo III was stigmatized in a similar way. The iconophile chronicler Theophanes Confessor says that Leo came from Germanicea, which implies that he was a native of Syria, "but," Theophanes adds, "as a matter of fact he came from Isauria"38. Isauria was a mountain district in south-eastern Asia Minor, famous for its robbers and stone-cutters. If I understand him correctly, Theophanes is saying that, physically speaking, Leo was a native of Syria, although in spiritual matters he was a rude Isaurian ${ }^{39}$. Thus, in the opinion of the defenders of icon worship, the icono-

${ }^{35}$ Cf. Kitzinger 1977, $120 \mathrm{f}$.

${ }^{36} \mathrm{Ib} .122$.

${ }^{37}$ PG 93, $77 \mathrm{~A}$. This translation differs to a certain degree from that of Gero 1973, 88.

${ }^{38}$ Theophanes 391,5f.

${ }^{39}$ My interpretation differs from the current explanation, according to which either the words "but as a matter of fact he was from Isauria" have been interpolated or Theophanes mixed up Leo III with the Emperor Leontius (695-98), who was an Isaurian. Ib. $407,17 \mathrm{ff}$., is a similar case. There, Germanos is supposed to have told Leo that he had heard that the attack on the icons would 
clastic reaction was a question of lack of education and understanding. But, uneducated or not, the iconoclasts seem to have been genuinely alarmed by the growing importance of the icons. They failed to see how this development could be reconciled with the Second Commandment. They had the feeling that Christianity was being invaded by pagan materialism, that the icons were forming an impenetrable wall between God and man.

The iconophiles did not share this feeling. According to them, the Old Testament prohibition referred to the making of idols and, in their opinion, the Christian images were portraits of real historical persons, not idols. Far from tying the mind of the Christian to material things the icon reminded him of the works of the saints and urged him to follow their example. Moreover, in their view, the icon was somehow related to its prototype, so that the veneration shown for the icon did not stay there but was transmitted to the person represented. Consequently the iconophiles could accuse the iconoclasts of showing disrespect for the saints.

The iconophiles did not try to depict God himself. In this respect, orthodox Christian art differed from the art of the pagans. But, according to Christian belief, God had appeared here on earth in the guise of a man, and they did not see why this man could not be depicted. On the contrary, to refrain from depicting him was, to their mind, tantamount to denying the Incarnation.

The answer ${ }^{40}$ of the iconoclasts to the argument from the Incarnation, which was developed by John of Damascus and became increasingly important during the controversy, was the christological dilemma pointed out by Constantine $\mathrm{V}$ and the bishops at Hiereia, namely, that Christ was not only man but also God. Since he was both God and man and the divine is beyond representation, a conventional portrait cannot do justice to the figure of Christ. This argument was applied to the images of the saints as well. According to the iconoclasts, the holiness of the saints could not be represented, and the images of the saints therefore give a false impression of their prototypes. In the eyes of the iconoclasts, art was something worldly that should not be allowed to interfere with the holy.

Thus, we have reached the point where we asked why iconoclasm failed. The answer appears to be implied in what has already been said. The iconoclasts of the first generation based their opposition on the Old Testament's prohibition against the making of graven images and likenesses. But a move-

come in the reign of Konon, not in the reign of Leo, and Leo is supposed to have answered: "In fact, my baptismal name is Konon." This story, which also appears in the libel called Adversus Constantinum Caballinum, PG 95, $336 \mathrm{C}$, does not seem to have been correctly understood by modern scholars. To my mind, it is simply based on the pun Konon-eikonon and is typical of the way in which the iconophile authors treated their opponents.

40 It should be borne in mind that this brief summary is based on modern reconstructions of the conflict. The exact order in which the arguments were put forward and refuted is very imperfectly known. 
ment that was based on the Law and not on Grace was unlikely to meet with lasting success in a Christian society. To people who had become used to icons, iconoclasm must have seemed out of focus and hard to understand $^{41}$. As we have seen, the iconoclasts were soon obliged to produce more up-to-date arguments. When the iconoclasts accused the Christians of having leamt pictorial art from the pagans, they were undoubtedly right. But even if pagan artistic tradition had been adopted by the Christians, the substance of their art was Christian. As Christ's second coming was delayed and Christianicy acquired a history, it was, in view of the cultural background, quite natural that the Christians should create an art on their own. It is understandable that the otherworldliness of the first Christians could not be maintained indefinitely. To a modern observer, it seems remarkable that the iconoclasts of the first generation did not limit themselves to trying to put an end to apparent abuse instead of attacking the images as such ${ }^{42}$. On one point, however, the iconoclasts yielded. At the Council of Hagia Sophia in 815 , they withdrew their accusation that icon worship was idolatry.

The christological objection, according to which the bread and wine of the Eucharist constitute the only true picture of the body of Christ, was more serious. This objection was hard to refute, as it was based on an orthodox doctrine and conformed with the fact that the Early Church had celebrated the Eucharist in a milieu void of pictures. Admittedly, there was something Early Christian, something sublime and pure about iconoclastic theory. But this was also its weak point. The iconoclasts made the religious feeling the slave of the intellect. They failed to see that there was a need for greater visualization, for something less mysterious than the bread and wine. According to the iconophiles, God had complied with this need by letting Himself be incarnated. Moreover, the Incarnation implied that God had accepted matter and abolished the dualism between the material and the spiritual worlds which had been such a problem in antiquity. The iconophiles therefore did not see why the artists should not follow God's example and on their part try to visualize the Incarnation. On the contrary, it seemed natural to them to take one further step and depict Christ enthroned in His heavenly glory. Thus, the beholder got a strong impression of Christ's presence. He had a feeling of being a part of the spiritual cosmos.

The iconophiles were of the opinion that the picture complements the word, as sight complements hearing. Hearing does not exclude sight; why then should the word exclude the picture? Rather, some iconophiles said,

41 Patriarch Germanos, Letter to Thomas, Bishop of Claudioupolis, PG 98, 184 C: "But now a large number of people are in no small commotion about this matter."

42 According to Beck, $13 \mathrm{ff}$, the iconoclasts were moderate at first and became radical on- ly because the iconophiles over-reacted. Yet, if the original aim of the iconoclasts just was to stop excessive worship, why did Leo III remove the image of Christ from above the entrance of the palace? 
the picture is superior to the word ${ }^{43}$, just as, according to an old saying ${ }^{44}$, sight is superior to hearing. At any rate, it is clear that the icon complements the Vita in more than one way. If you cannot read or if you have no time for reading a Vita, you can always look at the icon of the saint in question. Moreover, the Vita also complements the icon with regard to content. In principle, the Vita is a historical work. In it, the saint's life and good works are described. But, in the icon, he also appears in his present heavenly state, standing close to God and having God's ear; he enjoys parrêsia, as it was called. Thanks to his privileged position, he can plead the cause of the beholder before God, if the beholder asks for it. This gave the icon an appeal which at last defeated the iconoclasts' radical spirituality.

After the end of the iconoclastic controversy (843), the icons began to reappear in the churches and gradually claimed more space, according to a sophisticated, hierarchical plan. In the classical Middle Byzantine church, the holy persons looked at the visitor from the cupolas, the vaults and the walls in a way which gave him the impression of communicating with them and being integrated into their spiritual world ${ }^{45}$. Meanwhile, the altar was withdrawn from its previous advanced position into the apse. The chancel screen became increasingly opaque ${ }^{46}$. At last the iconostasis rose like a wall between the sanctuary and the rest of the church ${ }^{47}$. This did not mean, however, that what the iconoclasts had regarded as the only true image of Christ was superseded by the icons. It was rather that the different roles of the Eucharist and the icons become more distinct. The mysterious character of the Eucharist was further underlined, whereas the icons responded to the need for the visual, immediate and easily understandable.

\section{Bibliography}

TJhS The journal of theological studies

Alexander, P., 1958, The Patriarch Nicephorus of Constantinople. Oxford.

Anastos, M., 1955, The argument for iconoclasm as presented by the iconoclastic council of 754. Late classical and mediaeval studies in honor of Albert Friend, $J r$, ed. K. Weitzmann. Princeton.

Baynes, N., 1955, The icons before iconoclasm. Baynes, Byzantine studies and other essays. London.

Beck, H.-G., 1975, Von der Fragwürdigkeit der Ikone. Bayerische Akademie der Wissenschaften, Philosophisch-historische Klasse. Sitzungsberichte, 7. München.

${ }_{43}$ This point was especially stressed by $\mathrm{Pa}$ triarch Nicephorus I (806-15), cf. Lange $209 \mathrm{f}$, Beck $16 \mathrm{ff}$.

44 The most famous instance is Herodotus, History i.8,2, but, as Lange 15 points out, the iconophiles themselves did not refer it to the classical Greek authors.
45 For the system of Middle Byzantine church decoration, cf. Demus $14 \mathrm{ff}$.

${ }^{46} \mathrm{Cf}$. Mathews 179.

${ }^{47}$ The last step in this development was taken in the fourteenth century, Lazareff, 139, or perhaps already in the twelfth, cf. Chatzidakis 344. 
Brown, P., MacCormack, Sabine, 1975, Artifices of eternity. The New York review of books, 22, $20 \mathrm{Feb}$.

Cameron, A., 1978, The Theotokos in sixth-century Constantinople. JThS, 29.

Chatzidakis, M., 1973, Ikonostas. Reallexikon zur byzantinischen Kunst, 3, ed. K. Wessel and M. Restle. Stuttgart.

Demus, O., 1948, Byzantine mosaic decoration. London.

Gero, S., 1973, Byzantine iconoclasm during the reign of Leo III, with particular attention to the Oriental sources. Louvain.

- 1977, Byzantine iconoclasm during the reign of Constantine $V$, with particular attention to the Oriental Sources. Louvain.

Herodotus, 1927, History, ed. C. Hude. Oxford.

Kitzinger, E., 1954, The cult of images in the age before iconoclasm. Dumbarton Oaks Papers, 8.

- 1977, Byzantine art in the making. London.

Lange, G., 1968, Bild und Wort. Würzburg.

Lazareff, V., 1964, Trois fragments d'épistyles peintes et le templon byzantin. Deltion tês christianikês archaiologikês hetaireias, ser. 4, 3.

Léontios de Néapolis, 1974, Léontios de Néapolis, Vie de Syméon le Fou et Vie de Jean de Chypre, ed. commentée par A. Festugière en collaboration avec L. Rydén. Institut Français d'archéologie de Beyrouth. Bibliothèque archéologique et histologique, 95. Paris.

Mango, C., 1972, The art of the Byzantine empire. 312-1453. Sources and Documents in the History of Art Series, ed. H. Janson. Englewood Cliffs.

Mansi, J., $1759 \mathrm{ff}$, Sacrorum conciliorum nova et amplissima collectio. Florence.

Mathews, T., 1971, The early churches of Constantinople. University Park and London.

PG, 1857 ff., Patrologiae cursus completus, Series graeca. Rec. J. Migne. Paris.

Murray, Ch., 1977, Art and the early Church. JThS, 28.

Rydén, L. (ed.), 1963, Das Leben des heiligen Narren Symeon von Leontios von Neapolis. Uppsala.

- 1978, The date of the Life of Andreas Salos. Dumbarton Oaks Papers, 32 (in press).

Textus, 1969, Textus byzantinos ad iconomachiam pertinentes, ed. H. Hennephof. Leyden.

Theophanes, 1963, Chronographia, ed. C. de Boor. Leipzig.

Thümmel, H., 1978, Neilos von Ankyra über die Bilder. Byzantinische Zeitschrift, 71. 